\title{
Proposing a Post-heritage Critical Framework: The Crown, Ambiguity, and Media Self-consciousness
}

Television \& New Media

$1-17$

(C) The Author(s) 2019

Article reuse guidelines: sagepub.com/journals-permissions DOI: I0.1 I77/I5274764|9866427 journals.sagepub.com/home/tvn

@SAGE

\section{Will Stanford Abbiss'}

\begin{abstract}
This article proposes a new critical framework through which to analyze television period drama, recognizing elements that indicate a more progressive point of view than many previous scholarly responses have acknowledged. It begins by assessing the seminal works of Andrew Higson and Claire Monk in the field of period drama, adopting the latter's term of "post-heritage" to identify an alternative critical perspective. The five guiding elements of the proposed post-heritage framework are then outlined, with reference to pertinent critical works that identify these in period dramas and other production. A preliminary case study of The Crown is then offered, through which the post-heritage framework is demonstrated as an aesthetic methodological process. The Crown's use of the media within its narrative and conceptual ambiguity are considered particularly closely. The article concludes by suggesting the wider applications for the post-heritage critical framework, and potential further study relating to The Crown.
\end{abstract}

\section{Keywords}

post-heritage, television, period drama, The Crown, aesthetics, ambiguity

British-made television holds a significant, though often critically neglected, place in the development of period drama. Andrew Higson (2001, 249; 2003, 15), influential in establishing "heritage" drama as a generic category, traces the "contemporary fascination with period drama" to the dual appearance of Chariots of Fire on film

\footnotetext{
IVictoria University of Wellington, New Zealand

Corresponding Author:

Will Stanford Abbiss, School of English, Film, Theatre, and Media Studies, Victoria University of Wellington, 83 Fairlie Terrace, P.O. Box 600, Wellington 6140, New Zealand.

Email: will.abbiss@vuw.ac.nz
} 
and Brideshead Revisited (ITV) on television in 1981. Prior to this, "classic serial" literary adaptations established heritage fiction on television (Higson 1995, 26). Despite academic work on the latter form in particular (see Cardwell 2002; Giddings and Selby 2001; Kerr 1982), the later emergence of the television studies field means the definitions and contextualization of heritage screen fiction remains dominated by film studies approaches. Higson $(2006,91)$ characterizes the heritage film's display of the past as "visually spectacular pastiche, inviting a nostalgic gaze that resists the ironies and social critiques so often suggested narratively by these films," resulting in a "fantasy of Englishness" (Higson 2006, 96). Claire Monk $(2001,7)$ has considered the tension between aesthetics and narrative further, coining the term "post-heritage" to categorize "an emerging strand of period/literary films with a deep self-consciousness about how the past is represented" and offers a re-reading of earlier period drama films (Monk 2001, 9-10). Higson (2003, 85) has subsequently reframed his heritage theory, acknowledging Monk's perspective and asserting that heritage films are "ambivalent enough to be read in both ways, perhaps even at the same time." The historic categorization of heritage drama has therefore led to leftist critics dismissing productions "on class grounds" (Higson 2003, 46). Such critical dismissal is particularly apparent in Cairns Craig's $(2001,5)$ analysis of heritage cinema, which he describes as "situat[ing] us firmly in the barricaded room of an English identity from which the outside world is viewed from above and without, not engaged with."

A less dismissive outlook has been adopted to assess specific themes in period dramas, including sexuality (Monk 2001), homosexuality (Dyer 2001), and masculinity (Byrne et al. 2018). Nevertheless, and despite the progression in the field from Monk and Higson, neither a formal definition of post-heritage nor methodology for assessing period drama under its terms has been put forward. This article aims to provide this by developing post-heritage as a critical perspective, offering a theoretical framework through which all period drama can be assessed and thus recognizing that "there is no clear break" between heritage and post-heritage dramas (Higson 2003, 44). This framework proposes to evaluate a drama's political and ideological point of view, situated within its production's contemporary contexts. It should also acknowledge the diverse possible interpretations of period drama productions, recognizing genres "as loose, leaky, hybrid categories, drawing on a variety of influences" (Higson 2003, 10). Establishing post-heritage as a critical perspective, rather than a subgenre of period drama, will identify the elements of period drama that encourage cultural critique, even if they do not constitute the dominant ideology of a given production.

Within a post-heritage framework, the concept of drama cycles (as opposed to genres) will allow depictions of the past to be connected to contemporary culture. Again, this notion is indebted to Higson (2006, 93), who described "the heritage cycle and its particular representation of the past" in feature films of the 1980 s as "in many ways symptomatic of cultural developments in Thatcherite Britain." Monk's initial intervention identifies the post-heritage filmic cycle that followed this period, perhaps prefiguring the cultural shift toward New Labor's "Cool Britannia” (Higson 2003, 43). 
This cycle, according to Monk's analysis, is characterized by productions where the critiques of narrative dominate over the visual pleasures of heritage. My proposal of a post-heritage critical framework hypothesizes that a post-heritage cycle arises in television period drama of the 2010s, partly in response to the success of Downton Abbey (ITV1, 2010-2015). Monk (2015, 4-5) and Katherine Byrne (2015a, 69-70) have both connected Downton Abbey's popular success to the U.K. Conservative government that entered power in the year it began, drawing parallels to the 1980s heritage cycle. Subsequently, however, multiple productions have emerged that react against the perceived conservatism of Downton Abbey (Byrne 2015a, 2), resulting in a more "flexible and innovative" (de Groot 2016a, 223) perception of the past. The commonalities displayed by the dramas of this distinctly televisual cycle, as identified by recent scholarly work, will suggest the guiding principles of the post-heritage critical perspective. The benefits of television's capacity for serialization, beyond the classic serial's accordance to the novelistic form, will be particularly considered as allowing the televisual narrative to comprehensively realize post-heritage aspects.

Prioritizing the textual elements of television period drama constitutes an aesthetic approach, which has been subject to significant methodological debate in recent years. Sarah Cardwell (2006, 73), a major proponent of television aesthetics, argues for allowing the text to lead toward conceptual and philosophical questions while also mitigating the issues of an inherently evaluative approach (Cardwell 2006, 75). Cardwell $(2006,76)$ posits that "television aesthetics does not assume any particular hierarchy of texts or agreed canon, but it does address questions of value, critical judgement and the selection of criteria for evaluation." However, there are substantial difficulties in delineating a precise methodology applicable to all screen aesthetics (Geraghty 2003, 32; Jacobs 2006, 24). Nevertheless, within the specific realm of television period drama a post-heritage framework may suggest a workable methodology by which programs with a "disruptive edge" (Caughie 2006, 14) can be assessed. The approach I will propose makes conscious value judgments under specific criteria, thus avoiding the devaluing of an implicit "Other" (Hills 2011, 114); while some programs (i.e., those where the guiding post-heritage elements of cultural critique are more dominant) will be more conducive to a post-heritage reading than others, this does not refute or diminish the scholarly value of a "social, historical or cultural" approach to programs that benefit from this (Cardwell 2013, 39). For example, a "popular aesthetic" (Hills 2011, 114-6) approach to Downton Abbey, such as that undertaken by Rosalía Baena and Christa Byker (2015), is of indisputable critical worth, as are the multiple recent analyses of its transnational appeal and function (Gullace 2019; Magee 2018; Redvall 2019). While these are not methodologies I am pursuing, it does not mean that others should not.

This article will begin with a detailed outlining of the proposed post-heritage framework, which will outline its five guiding elements and situate these within the field of television aesthetics. It will continue with a case study of another highly successful period drama of the 2010s, Netflix's The Crown (2016-present). This will demonstrate the post-heritage methodology in practice, justifying the framework's guiding elements. The Crown's concept explores the tensions of presenting the royal 
family as the subject of a dramatic work, exploring Elizabeth II and her family as both private individuals and public figures to pursue an investigation into the monarchy's position in the modern era. This premise facilitates a post-heritage point of view, despite the aesthetic opulence in abundance throughout the high-budget serial. I am conscious of the irony of aligning my work with the field of television aesthetics, before immediately pursuing a case study approach in direct contradiction to Cardwell's $(2006,73)$ recommendation. My pre-emptive defense is that, on this occasion, an initial critical framework is required to make sense of the textual analysis that follows. The philosophical discussion that follows is reverse-engineered from textual examples, the thematic commonalities between which have guided my outlining of a postheritage framework. Through this, and the specificity of my focus on period drama, I avoid "broad theoretical perspectives" (Cardwell 2006, 77), allowing textual features to guide me toward "sociological, ideological and broader cultural matters" (Cardwell 2013, 23) rather than being led by them.

\section{A Post-heritage Framework}

The five guiding elements of a post-heritage critical perspective, as I define them, are interrogation, subversion, subjectivity, self-consciousness, and ambiguity. These characteristics are interrelated and often overlap throughout a screen production. Some programs embed a particular element within their concept, allowing the other elements to emerge from a central focus. In other productions, the five are addressed to more equal degrees. Regardless of this, the consistent deployment of these elements provides a sustained challenge to heritage tenets, revealing a production's dominant postheritage point of view.

Interrogation constitutes a critique of the ethos and value systems of heritage drama. Adopting an interrogative narrative means that the social hierarchies of the past are continually questioned, reducing any tendency toward nostalgia. As Higson (2001, 256) makes clear, while the visuals of heritage drama "suggest that this reductive view is both real and desirable," their narratives "are often much more radical, questioning the desirability of the lifestyle of those who inhabit these spaces." The distinction, then, is one of emphasis: whereas a heritage point of view sees an "emphasis on spectacle rather than narrative" (Higson 2006, 100), ultimately resisting the "ironies and social critiques so often suggested narratively" (Higson 2006, 91), a post-heritage point of view moves in the opposite direction. Emphasis on the more "liberal-humanist" (Higson 2006, 93) narrative therefore foregrounds the critical elements of period drama's conventions, limiting nostalgia for the historical past being depicted. Of course, one may interpret a production's ideological point of view in diverse ways, and whether the emphasis lies in its visuals or narrative may not be entirely clear. When considering long-form television narratives, however, it is possible to identify whether interrogative narratives are explored across multiple episodes of a series or serial or addressed and resolved within a single episode. The latter form's use of "interrelated and interdependent" episodes, an overarching story, and consistency of characters (Dunleavy 2018, 102-3) facilitates a sustained post-heritage interrogation over the 
serial's entire lifetime. This allows the interrogation of broader societal issues to be pursued alongside narratives that may resolve within a single episode.

Subversion allows the visual pleasures of heritage drama to be undermined, challenging social structures through visual means in addition to narrative critique. Heritage cinema is associated with distinct iconographies, as identified by Higson (2000, 212) in Howards End (1992):

Here is the small-country-house-come-large-cottage, the green and pleasant garden, the horse-drawn farming equipment, the charming people in their charming semi-rural heart of England setting. Here apparently is a timeless, traditional England in which Howards End, the house, can be read as the vessel of the core English identity, the homeland that must be conserved.

The household is of central importance to period drama, allowing the social hierarchies of the past to be shown in microcosm. Within this "heritage household," a "pleasure in the ornamental and the everyday" (Caughie 2000, 215) can be found, exemplified by the indulgences in dressing and food preparation of Upstairs, Downstairs (ITV, 1971-1975) (Wheatley 2005, 147-8). The pastoral landscape, meanwhile, allows the dramatic "space" to become a recognizable (and visitable) historical "place" (Higson 1987, 8), allowing screen productions to "play a crucial role as part of the larger heritage industry" (Higson 2001, 254). Brideshead Revisited, for example, impacted significantly upon its primary filming location, Castle Howard in North Yorkshire (Higson 2003, 58). Subverting heritage iconography reverses the movement from space to place, returning to a dramatic space while allowing familiar heritage elements to remain within the drama, reclaiming the "emotional affect" lost when the emphasis is on spectacle (Higson 2006, 100). Iris Kleinecke-Bates (2014, 68-76) provides a detailed analysis of various examples of subversion in The Woman in White (BBC One, 1997), operating through the juxtaposition of scenes, interior/ exterior contrast, and denying establishing shots of the country house setting. Crucially, subversion also allows the dramatic space to be inhabited by a wider demographic than the familiar upper-middle English classes. Richard Dyer (2001) and Julianne Pidduck (2001, 2004), for instance, consider diverse sexualities in period drama in relation to clothing, establishing the symbolic function of subverting the heritage preoccupation with dressing to that of undressing. Subversion may also reverse the reduction of British culture into a "fantasy of Englishness" (Higson 2006, 92), preventing other nations and cultures from being subsumed by "homogenous images of class, gender and nation" (Vidal 2012, 12). A broader interpretation of "Britishness" allows the term to be applied to a production's conceptual, creative or industrial contexts (Leggott 2008, 8-10), precluding the need for any physical British setting.

Subjectivity, often the result of subversion, displays a movement toward psychological investigation of character and the exploration of identities. This is primarily indicated by a program's aesthetic features, through which the interiority of central characters is explored, often in contrast to their outward or public personas. Arguing the "essentially hybrid and impure nature of the heritage film texts," Monk (1995, 
122) asserts that they offer "spaces in which identities . . . are shifting, fluid and heterogeneous." Screen productions where post-heritage elements dominate take advantage of these spaces, facilitating an intensive exploration of identity that challenges the assumptions of the social hierarchy. Subjectivity therefore allows the narratives of individual characters to be connected to broader cultural themes. The convergence of film and television aesthetics in recent years permits subjectivity to be developed; while previous technological restrictions saw the objective television camera hailed as allowing "total involvement of an emotional kind" (Kennedy Martin 1964, 31), the subjective look (previously the preserve of cinema) is now possible in television drama. To negotiate the tension between objectivity and subjectivity, the viewer becomes "active as a producer of meaning, working to produce her own understanding of the relationship between the elements of the drama" (Caughie 2000, 114). As established by Kristyn Gorton (2006, 77-8), audiences can construct meaning through negotiating their emotional responses to characters and connecting these to societal issues. This potential is not restricted to contemporaryset drama; Belén Vidal's $(2012,44)$ analysis of The Queen (2006) establishes how "the historical gaze is productively extended to the reframing of (internal) personal dilemmas as (external) historical conflicts in The Queen and, by extension, the heritage film." Subjectivity in period drama therefore allows the past to be depicted as impactful on the present, with the active viewer able to apply its narrative critiques to contemporary issues.

Self-consciousness further applies the viewer's construction of meaning to the present day, confirming the continued relevance of narrative events. This post-heritage aspect recognizes a screen production's historiographical role, positioning it as an interpretation refracted through the attitudes of the period it was made in and thus acknowledging the impossibility of complete authenticity. The effect of self-consciousness can be found in the long-standing tradition of "informational epilogues or epigraphs" (de Groot 2016b, 42) and the direct use of anachronistic phrases, as identified by Colin McArthur $(1980,37)$ in Edward the Seventh (ITV, 1975) and Upstairs, Downstairs (McArthur 1980, 42). It can also be more subtly displayed through the implications of dialogue or themes. Innovations to the period drama form often display self-consciousness, through diverse elements such as the twenty-first century framing narrative of The Village (BBC One, 2013-2014) or the looks to camera and anachronistic popular music of Vanity Fair (ITV, 2018). Self-consciousness may also be foregrounded in the marketing of a production, prevalent for literary adaptations shown as part of Masterpiece in the United States (West and Laird 2011, 308; Weissmann 2012, 106). Within the category of self-consciousness lies self-reflexivity, which refers to the specific recognition of a production's status as a media text. This may be achieved through intertextual references to earlier period dramas, or by featuring the screen medium itself within the drama. As well as applying the past to the present, self-consciousness allows British cultural narratives to be applied internationally, recognizing the universality of its character-focused and societal themes. The active viewership important to subjectivity continues to apply here, with viewers producing meanings relevant to their own cultural situation. Self-conscious 
elements of period drama encourage active viewership and the recognition of the screen text as non-authoritative.

Ambiguity at a narrative level acknowledges the inherent ambivalence of period drama (Higson 2003, 85), refusing to offer definitive responses to the cultural questions contained within. Higson $(2003,85)$ further notes that "the nostalgic sensibility is itself profoundly ambivalent, involving as it does a dialogue between the imagined past and a vision of the present." From a post-heritage critical perspective, it can be established that some productions foreground their inherent ambivalence, allowing a multiplicity of interpretations to remain valid and denying the anticipated catharsis of narrative closure. This prevents the broader societal tensions investigated by the narrative from being resolved, even when characters' individual stories reach a conclusion. As with interrogation, ambiguity is often aided by the use of a serial form, which allows depictions of the past to remain open to diverse interpretations. The post-heritage question posed by Monk $(1995,122)$ finds new relevance in relation to conceptual ambiguity:

Do [Chariots of Fire and Maurice (1987)] really make us nostalgic for a past in which British Jews were expected to live with anti-Semitic abuse and gay men could be sent to jail for kissing, or does our pleasure derive from cathartic indignation at the injustices of that past and the satisfaction of distancing ourselves from these prejudices in the present?

This inherent ambivalence is presented within the narratives of productions where ambiguity plays a central role and may even deny final catharsis by suggesting that the problems of the past remain present today. Ambiguity can also be explored in tandem with subjectivity, with serialized narratives facilitating the psychological investigation of central characters over numerous episodes (Dunleavy 2018, 103). The ambiguous motivations of an individual character are usually connected to their role in society, and implicitly to the equivalent position in the twenty-first century. Sarah E. Fanning's (2018) evaluation of the brooding Thornton in North \& South (BBC One, 2004) provides an exemplar for this ambiguous approach to character.

Adopting a post-heritage critical framework raises questions regarding the aesthetics of period drama, which warrant investigation beyond the scope of this article. Presently, and by way of transitioning to my case study of The Crown, I will briefly parse the discussions around postmodernism and depictions of the past. As indicated above, a post-heritage investigation of subjectivity often entails movements away from realism. The intertextuality foregrounded by self-consciousness is also a distinctly postmodern movement (Allen 2011; J. Collins 1992). However, Jameson's (1991) view of postmodernism argues that heritage drama's emphasis on spectacle causes a "typically postmodern loss of emotional affect" (Higson 2003, 40; 2006, 100). It is important to consider, therefore, whether postmodernism distances us from the past, holding it at a "reverential distance" (Higson 2006, 100) or brings us closer to it through "irreverence towards canonical narratives" (Pidduck (2001, 131). Negotiating these apparent contradictions requires recognition of multiple possible interpretations of postmodernism itself (Huyssen 1981), compounded by 
ambiguous period drama narratives. A post-heritage critical perspective foregrounds the interrelations between its five guiding elements, recognizing that in isolation they do not necessarily suggest a less conservative point of view. However, when operating in conjunction throughout a series or serial's lifetime, they do indicate a left-leaning approach to the British cultural past. It could therefore be argued that television period drama of the 2010s displays a postmodern syncretism (Gutleben 2001, 221-3), blending conventions and perspectives in its narratives, aesthetics, and conceptual ideologies.

\section{The Crown: A Preliminary Case Study}

The Crown interrogates the role of the monarchy in contemporary society through the central characters of Elizabeth II (Claire Foy) and her immediate family. Elizabeth's conflict between public role and private identity uses a tradition stretching back to Shakespeare's history plays; it innovates the formula, however, through its central use of post-heritage elements. At a conceptual level, the personal conflicts felt by Elizabeth, Prince Philip (Matt Smith), and Princess Margaret (Vanessa Kirby) are framed as representing broader societal issues, relevant to the 2010s as much as the 1950 s and 1960s. The Crown's self-conscious approach is first suggested by its title, which rejects the traditional form of "Elizabeth II" in favor of reflecting its concept's broader concerns. It also adopts a serial form, allowing its character's conflicted situations and questions regarding the monarchy's role in society to continually resist closure, even when an individual storyline resolves within the space of an episode. Interrogation, self-consciousness, and ambiguity are therefore embedded in the serial's concept, allowing a post-heritage point of view to consistently dominate the more conservative heritage visuals. Within this, subjectivity is frequently used to expose the disjunction between public and private roles in The Crown's central characters.

The recurring motif of the media-via photography, newspaper journalism, and television reports - allows for elements of self-consciousness and self-reflexivity to persist and develop across The Crown's first two seasons. Many episodes feature the disorienting burst of camera flashbulbs, the first significant example occurring as Elizabeth returns home following her father's death (S1 E2, "Hyde Park Corner"). As the new Queen disembarks her plane, shutters sound and flashbulbs light as one, before the row of assembled journalists quickly bow their heads in deference. The disorienting impact of this auditory and visual burst illustrates Elizabeth's emotional turmoil as both grieving daughter and newly acceded monarch, with the news media representing the intrusion of her public role. Strikingly, the photographers prioritize their photo opportunity before showing due respect to Elizabeth, displaying a level of impropriety in their act of mediatization. This moment exposes the complexities of depicting still-living members of the royal family and the negotiation of voyeurism and respect that The Crown sustains. The Crown therefore not only places itself within a tradition of media representations of royalty, but opens its act of representation to criticism; rather than evading these ideological issues, the serial acknowledges its historiographical status and permits its viewers to draw diverse conclusions. 
Elizabeth's coronation allows The Crown to incorporate overt self-conscious commentary within its narrative. The grand ceremony allows the aesthetic pleasure of heritage drama to be felt, placing the twenty-first century viewer in a privileged position compared with their 1953 counterparts. The technological developments across the intervening decades are also foregrounded, displayed in a shot that begins with the black-and-white image captured by the viewfinder of a BBC camera while the reenactment below is obscured by soft focus (S1 E5, "Smoke and Mirrors"). The shot focus then shifts, obscuring the black-and-white archival footage and revealing the full high-definition splendor of the 2016 dramatization. The Crown's act of recreation is thus exposed, contrasting the inescapable unreality of its performances with its aesthetic superiority. The shot moves from the naturalism of the 1953 filming to realism, allowing the viewer to recognize the serial's conceptual limitations. This can be read as a Brechtian movement, negotiating the tension between objectivity and subjectivity by acknowledging disparate elements and allowing the viewer to construct meaning (Caughie 2000, 113-4). The construction of meaning is aided by the self-conscious commentary of the Duke of Windsor, formerly King Edward VIII (Alex Jennings), whose television viewing of the coronation from Paris is cross-cut with the ceremony itself. Foregrounding an abdicated monarch during the coronation sequence allows the vulnerability of the monarchy to remain in focus, even amid visual ostentation. The double viewpoint of the Duke's subjectivity in 1953 and the viewer's in 2016 also allows the coronation's status as a transnational televisual event (Hilmes 2012) to be made apparent - the Duke entertains American guests in France, deciphering for them the liturgy of the British ceremony. As Elizabeth's consecration begins, the Duke and his assembled viewers in 1953 are prohibited from viewing the sacred moments because, in the Duke's words, "we are mortal" ("Smoke and Mirrors"). However, the twenty-first century viewer is invited into this privileged space and sees the Queen's anointing in close-up. This entry into a space explicitly denied to television viewers of the time further legitimizes the twenty-first century viewpoint as more comprehensive than that of the 1950s, contrasting the insight of the dramatization with the limited viewpoint of history. Realism has now moved toward postmodernism, foregrounding the multiple representations and perspectives that The Crown is placed within.

As The Crown continues, the subjectivity of Princess Margaret allows the serial to develop its self-conscious approach to history. Margaret is frequently shown looking toward the camera, often refracted through newspaper print or a television screen. She enacts the "exchange of looks" found in documentary drama (Caughie 1981, 347), but casts the viewer rather than other characters as a referent. The viewer's role as constructor of meaning is emphasized during Margaret's affair with Peter Townsend (Ben Miles), a story largely told through its status as a press scandal, and often through anachronistic allusions. In the most striking example, Margaret and Peter's car is pursued at high speed by a group of photographers (S1 E10, "Gloriana”), evoking uncomfortable memories of Princess Diana's death in 1997. In another scene, a private conversation between Margaret and Peter ends in a long-shot as the two kiss passionately (S1 E6, "Gelignite"). The cinematography suggests the possibility of press intrusion, calling to mind the 2012 scandal around long-lens topless photographs of the 
Duchess of Cambridge (O'Carroll and Willsher 2012). In The Crown, there is no further indication that the moment between the fictionalized Margaret and Peter was photographed; it is the dramatization itself that is performing the act of voyeurism and of exploitation.

In season 2, Margaret meets her eventual husband, the unconventional photographer Tony Armstrong-Jones (Matthew Goode). Tony's profession allows the act of photography to be foregrounded, in conjunction with the established motif of media representation. Tony's artistic approach is contrasted with the traditionalism of Cecil Beaton (Mark Tandy), who is charged with taking Margaret's birthday photograph (S2 E4, "Beryl"). The debate around Beaton's style permits The Crown to present its most self-reflexive moment, via the Queen Mother's (Victoria Hamilton) defense of his "fairy tale" imagery: "No one wants complexity and reality from us ... People have enough of that in their own lives; they want us to help them escape" ("Beryl"). Beaton himself embraces the Queen Mother's theme in highly paternalistic tones, defending his approach to a skeptical Margaret:

Imagine this, if you will: a young woman, a commonplace creature. She sits in her drab little scullery; so much work to do, so much ... washing-up. How she longs for comfort, for hope ... She wants to believe her life has some meaning, beyond chores. She opens a magazine, and she sees Her Royal Highness' photograph. For one glorious, transforming moment, she becomes a princess too. She is lifted out of her miserable, pitiful reality into a fantasy. ("Beryl")

Margaret's rejection of this ideology in favor of Tony's thus represents a rejection of heritage drama's escapism. Margaret's desire for authenticity combines with a rejection of the institutional, as suggested in her initial description of Tony: "There's a contempt in him ... For me, for us, for everything we represent" ("Beryl"). Tony acts in accordance, searching for a perfect photograph of the "real" Margaret by assuming the role of audience surrogate, probing her affair with Peter and the difficulty of seeing beyond the monarchy's "fairy tale." The resultant photograph, staged so Margaret appears to be naked, offers a different frisson of scandal to the characters of the drama and the twenty-first century viewers. At the end of the episode, the image is presented underneath the credit sequence, cropped to the serial's widescreen aspect ratio. The image now excludes Margaret's shoulders, and most of her lips, precluding the sexual undertones of the full image and making her eyes the focal point. Pictured outside of the narrative, Margaret is looking directly at viewers of The Crown, exposed psychologically rather than physically. The viewer is thus encouraged to undertake their own search for the "real" Margaret.

Following season 1's justification of its post-heritage project, season 2 of The Crown is able to widen its scope and incorporate additional figures, pursuing the overarching narrative of questioning the monarchy's role in the modern era from diverse perspectives. The concurrent use of documentary material does not detract from the serial's interpretations and suppositions, but rather continues to acknowledge the ambiguous nature of its narrative. In addition, the presence of nonfictional material shows The Crown's historiographical function and its continued movement 
toward postmodernism through intertextuality. The fifth episode of season 2 ("Marionettes") concerns another media storm, this time regarding Lord Altrincham's (John Heffernan) criticisms of the monarchy. The episode ends with captions that relate the Palace's subsequent (historical) recognition that "Lord Altrincham did as much as anyone in the $20^{\text {th }}$ Century to help the monarchy," and Altrincham's renunciation of his title ("Marionettes"). This is followed by an image of "John Grigg," the name Altrincham reverted to, and the historical figure behind the episode's Altrincham. Grigg, naturally, appears noticeably dissimilar to his preceding portrayal by Heffernan in this image. Separating the personas of Altrincham and Grigg establishes the significance of his renounced peerage and also the difference between dramatized character and historical figure. This distinction is maintained in the following episode, where approaches to documentary history begin to impact the serial's narrative. This episode re-introduces the Duke of Windsor against the emergence of the Marburg Files, which contain information suggesting the Duke's Nazi affiliations (S2 E6, "Vergangenheit"). This documentary evidence is literally passed between characters over the course of the episode, allowing it to be interpreted from multiple perspectives. The burden of how to respond to the files ultimately falls to Elizabeth, presenting her with another conflict between private and public responsibilities. It is not documentary evidence but the additional first-hand recollections of private secretary Tommy Lascelles (Pip Torrens) that condemns the Duke of Windsor and persuades Elizabeth to deny him forgiveness. Lascelles holds his own stated bias toward the Duke, however, and his evidence is presented without supporting documentation, maintaining ambiguity around the Duke's true motivations. The episode ends with further historical documents, through a montage of a series of archive photographs depicting the Duke of Windsor's 1937 visit to Nazi Germany, including his meeting with Hitler ("Vergangenheit"). These troubling images assert the historical basis for the episode, but are still not definitive; as the narrative use of the Marburg Files establishes, historical documentation's objectivity is insufficient when pursuing deeper representative truths.

Season 2's developed use of nonfictional imagery culminates in its seventh episode, which depicts the marriage of Margaret and Tony. The heritage characteristic of dressing is subverted by non-diegetic means prior to the Westminster Abbey ceremony, when various members of the royal family are shown preparing for the occasion (S2 E7, "Matrimonium"); the montage is underscored by surprisingly somber music, and furthermore all its characters appear troubled for reasons not explicit in the narrative. The dissonantly morose tone encourages the viewer to recall their prior knowledge of this marriage, in particular that it will not be a success. While Margaret herself is not part of this montage, subjectivity remains of central importance: the editing of the sequence suggests Elizabeth and Philip looking toward each other, although they are in separate locations, and the other royal characters in the montage all scrutinize themselves in the mirror. Investigation of these characters and their nonfictional antecedents is further encouraged by the deployment of archival television and radio commentary over the sequence, placing the televisual dressing sequence in its historical context. The sequence concludes with the figure of Jacqui 
Chan, one of Tony's several lovers (her presence further compromising Margaret and Tony's imminent commitment), whose television set continues the news report of the wedding. On the television screen, Margaret and Tony face away from the camera, and as they turn, they are revealed to be their nonfictional, documentary iterations ("Matrimonium"). The "real" Margaret and Tony appear conspicuously within the work of dramatization, aligning Margaret's persistent looks to camera with her nonfictional counterpart, as the distinction between the two is simultaneously emphasized. The real has intruded on the space of drama, stymieing any inclination to view the wedding from a nostalgic point of view. On this occasion, and in contrast with Elizabeth's coronation, the viewer is not permitted to view the interior of Westminster Abbey; the episode closes with an exterior shot of the Abbey, while archival audio of Margaret and Tony's vows is heard ("Matrimonium"). It is now the viewers of 1960 who hold the privileged viewpoint, while the implied visual pleasure of the ceremony is withheld from the audience of The Crown. However, the use of historical images in the second season allows the serial's viewer to recognize that a nuanced understanding of the past lies away from ostentatious aesthetics. Shutting the doors of Westminster Abbey, as part of a postmodern layering of the fictional and nonfictional, allows these unresolved complexities to remain in focus, even during an ostensibly joyous occasion.

\section{Placing in Context}

The critical framework of post-heritage I here propose does not intend to encourage categorization, or indeed a "canon," within television period drama, but instead to identify the specific narrative and aesthetic characteristics that enact a cultural critique. Although I suggest that a post-heritage "cycle" exists in television drama of the 2010s, the proposed critical reading should not be restricted to contemporary productions; as Monk (2001) established when coining post-heritage, the term may also be used to re-assess previous television productions. Particularly ripe for a revised reading are the triumvirate of Upstairs, Downstairs, Brideshead Revisited, and The Jewel in the Crown (ITV, 1984), scholarly responses to which (Brandt 1993; R. Collins 1990; Freedman 1990; Thornton 1993; Wollen 1991) have tended to focus on their heritage and nostalgic characteristics. A post-heritage reading may also be applied to dominantly conservative productions; as Higson (2003, 2006) establishes, heritage dramas usually contain elements of narrative critique to some degree. Byrne (2015a, 66-89; 2015b) has indeed directly attempted a post-heritage reading of Downton Abbey, though she fails to fully acknowledge that the elements she identifies are exceptions to the series' dominant conservative ideology. Another of Byrne's (2015a, 147-9) examples indicates the importance of a production's overall ethos, as she analyses an episode of The Village that interrogates the act of remembrance after the First World War. This issue also features in the fifth season of Downton Abbey, but rather than forming the emotional core of an episode, it is subordinate to the dominant focus on character; most discussions of the village memorial are used to explore a shift in dynamic between Lord Grantham and his 
butler, with the objections to a public memorial quickly resolved around the dinner table. Productions that offer innovations on period drama characteristics, particularly those taking a left-leaning point of view, are therefore likely to suggest broader cultural and sociological meanings when subjected to a post-heritage reading, as suggested by several earlier studies (de Groot 2016a; Dyer 2001; Monk 2001; Pidduck 2001; West and Laird 2011). The post-heritage framework also recognizes the complexities of screen productions, acknowledging the inadequacy of applying a single ideological viewpoint to the collaborative medium of television. This is achieved through criteria that assess the dominant impression of a screen text, recognizing any contradictions or ideological shifts that become apparent across a production's entire lifetime.

The Crown maintains an overriding ambiguity around its central concept, allowing for the monarchy to be both criticized and supported depending on the viewer's own disposition. The aesthetic pleasures of heritage drama are frequently apparent, but are challenged and at times subverted by the sustained interrogation undertaken by The Crown's serialized narrative. Furthermore, the self-conscious use of documentary referents allows the serial's place within the context of other representations of royaltyboth fictional and nonfictional- to retain focus. The Crown's approach to its central characters sustains its ambiguity, with Elizabeth's public/private conflict developed but ultimately unresolved at the end of season 2. Her marriage to Philip is equally complex (and also without a definitive resolution), and Philip's complex masculinity is another central theme that "The Crown allows scope for viewers to make their own judgement on" (Leggott 2018, 274). The serial's facilitation of multiple interpretations opens it to a wide range of critical responses, justifying further analysis. The evaluative criteria of the post-heritage critical framework therefore establish it as an important indicator of period drama's potential in the 2010s. The dominant post-heritage elements of The Crown allow the intricacies of its ideological project to be recognized, preventing it from critical dismissal under heritage terms.

The above preliminary case study of The Crown displays the benefits of approaching television period drama from a post-heritage perspective, particularly for works produced in the 2010s. The post-heritage critical framework allows for a drama's innovative characteristics to be recognized alongside aspects of conventionality, identifying the dominant ideological thrust of its concept without imposing the binary opposition of categorizing dramas as "heritage" and "post-heritage." This provides a methodology through which the value judgments of an aesthetic approach to television can be formally justified, allowing critics "to investigate what broader questions arise from that process of examination and exploration" (Cardwell 2006, 73). This approach is particularly apposite for television of the 2010s, where institutional and technological developments have allowed more conceptually and aesthetically innovative period dramas to emerge.

\section{Declaration of Conflicting Interests}

The author declared no potential conflicts of interest with respect to the research, authorship, and/or publication of this article. 


\section{Funding}

The author received no financial support for the research, authorship, and/or publication of this article.

\section{ORCID iD}

Will Stanford Abbiss (iD) https://orcid.org/0000-0001-5451-3360

\section{References}

Allen, Graham. 2011. Intertextuality. 2nd ed. London: Routledge.

Baena, Rosalía, and Christa Byker. 2015. "Dialects of Nostalgia: Downton Abbey and English Identity." National Identities 17 (3): 259-69.

Brandt, George W. 1993. "The Jewel in the Crown (Paul Scott-Ken Taylor): The Literary Serial; Or the Art of Adaptation." In British Television Drama in the 1980s, edited by Brandt, 196-213. Cambridge: Cambridge University Press.

Byrne, Katherine. 2015a. Edwardians on Screen: From Downton Abbey to Parade's End. Basingstoke: Palgrave Macmillan.

Byrne, Katherine. 2015b. "New Developments in Heritage: The Recent Dark Side of Downton 'Downer' Abbey." In Upstairs and Downstairs: British Costume Drama Television from The Forsyte Saga to Downton Abbey, edited by James Leggott and Julie Anne Taddeo, 177-90. Lanham: Rowman \& Littlefield.

Byrne, Katherine James Leggott, and Julie Anne Taddeo, eds. 2018. Conflicting Masculinities: Men in Television Period Drama. London: I.B. Tauris.

Cardwell, Sarah. 2002. Adaptation Revisited: Television and the Classic Novel. Manchester: Manchester University Press.

Cardwell, Sarah. 2006. "Television Aesthetics." Critical Studies in Television 1 (1): 7280.

Cardwell, Sarah. 2013. "Television Aesthetics: Stylistic Analysis and beyond." In Television Aesthetics and Style, edited by Jason Jacobs and Steven Peacock, 23-44. London: Bloomsbury.

Caughie, John. 1981. "Progressive Television and Documentary Drama." In Popular Film and Television, edited by Tony Bennett, Susan Boyd-Bowman, Colin Mercer, and Janet Woollacott, 327-52. London: British Film Institute.

Caughie, John. 2000. Television Drama: Realism, Modernism, and British Culture. Oxford: Oxford University Press.

Caughie, John. 2006. "Telephilia and Distraction: Terms of Engagement." Journal of British Cinema and Television 3 (1): 5-18.

Collins, Jim. 1992. "Television and Postmodernism." In Channels of Discourse, Reassembled: Television and Contemporary Criticism, edited by Robert C. Allen, 327-51. New York: Routledge.

Collins, Richard. 1990. Television: Policy and Culture. London: Unwin Hyman.

Craig, Cairns. 2001. "Rooms without a View." In Film/Heritage/Literature: A Sight and Sound Reader, edited by Ginette Vincendeau, 3-6. London: British Film Institute.

de Groot, Jerome. 2016a. Consuming History: Historians and Heritage in Contemporary Popular Culture. 2nd ed. Oxon: Routledge.

de Groot, Jerome. 2016b. Remaking History: The Past in Contemporary Historical Fictions. London: Routledge. 
Dunleavy, Trisha. 2018. Complex Serial Drama and Multiplatform Television. New York: Routledge.

Dyer, Richard. 2001. "Nice Young Men Who Sell Antiques: Gay Men in Heritage Cinema." In Film/Literature/Heritage: A Sight and Sound Reader, edited by Ginette Vincendeau, 43-48. London: British Film Institute.

Fanning, Sarah E. 2018. “A Post-feminist Hero: Sandy Welch's North and South.” In Conflicting Masculinities: Men in Television Period Drama, edited by Katherine Byrne, James Leggott, and Julie Anne Taddeo, 91-110. London: I.B. Tauris.

Freedman, Carl. 1990. "England as Ideology: From Upstairs, Downstairs to a Room with a View." Cultural Critique 17:79-106.

Geraghty, Christine. 2003. "Aesthetics and Quality in Popular Television Drama." International Journal of Cultural Studies 6 (1): 25-45.

Giddings, Robert, and Keith Selby. 2001. The Classic Serial on Television and Radio. Basingstoke: Palgrave Macmillan.

Gorton, Kristyn. 2006. “A Sentimental Journey: Television, Meaning and Emotion.” Journal of British Cinema and Television 3 (1): 72-81.

Gullace, Nicoletta F. 2019. "A (Very) Open Elite: Downton Abbey, Historical Fiction and America's Romance with the British Aristocracy." Journal of British Cinema and Television 16 (1): 9-27.

Gutleben, Christian. 2001. Nostalgic Postmodernism: The Victorian Tradition and the Contemporary British Novel. Amsterdam: Rodopi.

Higson, Andrew. 1987. "The Landscapes of Television.” Landscape Research 12 (3): 8-13.

Higson, Andrew. 1995. Waving the Flag: Constructing a National Cinema in Britain. Oxford: Clarendon Press.

Higson, Andrew. 2000. "National Cinema(s), International Markets and Cross-cultural Identities." In Moving Images, Culture and the Mind, edited by Ib Bondebjerg, 205-14. Luton: University of Luton Press.

Higson, Andrew. 2001. "Heritage Cinema and Television." In British Cultural Studies: Geography, Nationality, and Identity, edited by David Morley and Kevin Robins, 249-60. Oxford: Oxford University Press.

Higson, Andrew. 2003. English Heritage, English Cinema: Costume Drama since 1980. Oxford: Oxford University Press.

Higson, Andrew. 2006. "Re-presenting the National Past: Nostalgia and Pastiche in the Heritage Film." In Fires Were Started: British Cinema and Thatcherism, edited by Lester Friedman, 91-109. London: Wallflower Press.

Hills, Matt. 2011. "Television Aesthetics: A Pre-structuralist Danger?" Journal of British Cinema and Television 8 (1): 99-117.

Hilmes, Michele. 2012. Network Nations: A Transnational History of British and American Broadcasting. London: Routledge.

Huyssen, Andreas. 1981. "The Search for Tradition: Avant-Garde and Postmodernism in the 1970s." New German Critique 22:23-40.

Jacobs, Jason. 2006. "Television Aesthetics: An Infantile Disorder." Journal of British Cinema and Television 3 (1): 19-33.

Jameson, Fredric. 1991. Postmodernism, Or, the Cultural Logic of Late Capitalism. Durham: Duke University Press.

Kennedy Martin, Troy. 1964. "Nats Go Home: First Statement of a New Drama for Television." Encore 11 (2): 21-33.

Kerr, Paul. 1982. “Classic Serials-To Be Continued.” Screen 23 (1): 6-19. 
Kleinecke-Bates, Iris. 2014. Victorians on Screen: The Nineteenth Century on British Television, 1994-2005. Basingstoke: Palgrave Macmillan.

Leggott, James. 2008. Contemporary British Cinema: From Heritage to Horror. London: Wallflower Press.

Leggott, James. 2018. "No Need to Matronise Me!' The Crown, the Male Consort and Conflicted Masculinity.” In Conflicting Masculinities: Men in Television Period Drama, edited by Katherine Byrne, James Leggott, and Julie Anne Taddeo, 259-77. London: I.B. Tauris.

Magee, Gayle Sherwood. 2018. "Revisiting Gosford Park: Downton Abbey, American Audiences and the British Heritage Genre." In Exploring Downton Abbey: Critical Essays, edited by Scott F. Stoddart, 32-49. Jefferson, IA: McFarland.

McArthur, Colin. 1980. Television and History: Television Monograph. London: British Film Institute.

Monk, Claire. 1995. "The British 'Heritage Film' and Its Critics.” Critical Survey 7 (2): $116-24$.

Monk, Claire. 2001. "Sexuality and Heritage." In Film/Literature/Heritage: A Sight and Sound Reader, edited by Ginette Vincendeau, 6-11. London: British Film Institute.

Monk, Claire. 2015. "Pageantry and Populism, Democratization and Dissent: The Forgotten 1970s." In Upstairs and Downstairs: British Costume Drama Television from The Forsyte Saga to Downton Abbey, edited by James Leggott and Julie Anne Taddeo, 3-22. Lanham: Roman \& Littlefield.

O'Carroll, Lisa, and Kim Willsher. 2012. "Kate Topless Photos: Closer 'Has Broken French Privacy Laws." The Guardian, September 14. https://www.theguardian.com/uk/2012/ sep/14/kate-middleton-topless-photos-privacy-laws.

Pidduck, Julianne. 2001. "Elizabeth and Shakespeare in Love: Screening the Elizabethans." In Film/Heritage/Literature: A Sight and Sound Reader, edited by Ginette Vincendeau, 130-35. London: British Film Institute.

Pidduck, Julianne. 2004. Contemporary Costume Film: Space, Place and the Past. London: British Film Institute.

Redvall, Eva Novrup. 2019. "Mainstream Trends and Masterpiece Traditions: ITV's Downton Abbey as a Hit Heritage Drama for Masterpiece in the United States." In Transatlantic Television Drama: Industries, Programs, \& Fans, edited by Matt Hills, Michele Hilmes, and Roberta Pearson, 131-45. New York: Oxford University Press.

Thornton, Edith P. 1993. "On the Landing: High Art, Low Art, and Upstairs, Downstairs." Camera Obscura 11 (1): 26-47.

Vidal, Belén. 2012. Heritage Film: Nation, Genre and Representation. London: Wallflower Press.

Weissmann, Elke. 2012. Transnational Television Drama: Special Relations and Mutual Influence between the US and UK. Basingstoke: Palgrave Macmillan.

West, Nancy, and Karen E. Laird. 2011. "Prequels, Sequels and Pop Stars: Masterpiece and the New Culture of Classic Adaptation." Literature/Film Quarterly 39 (4): 306-26.

Wheatley, Helen. 2005. "Rooms within Rooms: Upstairs Downstairs and the Studio Costume Drama of the 1970s." In ITV Cultures: Independent Television over Fifty Years, edited by Catherine Johnson and Rob Turnock, 143-58. Maidenhead: Open University Press.

Wollen, Tana. 1991. "Over Our Shoulders: Nostalgic Screen Fictions for the 1980s." In Enterprise and Heritage: Crosscurrents of National Culture, edited by John Corner and Sylvia Harvey, 178-93. London: Routledge. 


\section{Author Biography}

Will Stanford Abbiss is a PhD student in the School of English, Film, Theater and Media Studies at Victoria University of Wellington, New Zealand. His doctoral study focuses on British-produced television period drama of the 2010s, reading from a "post-heritage" perspective. He recently presented a paper on The Crown (Netflix, 2016-present) at an international conference in Aarhus, Denmark. 